\title{
Is this essential for Japan to changes its LNG import policy? Some evidence of the OPEC crude oil price shocks
}

\section{Mostafa Raeisi Sarkandiz}

Faculty of Economics and Management, University of Tabriz, Tabriz, Iran

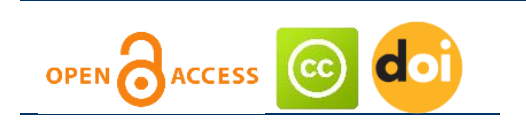

Article history:

Received: February 12, 2020

1st Revision: February 25, 2020

Accepted: April 10, 2020

JEL classification:
C32
Q41
Q43

DOI:

10.14254/jems.2020.5-1.3

\begin{abstract}
In this study, Japan's LNG import contracts are discussed. Given the importance that these contracts are oil-indexation, the impact of crude oil price volatility (emphasizing OPEC oil basket) on LNG prices was studied using a structural VAR model from January 1997 to October 2017. Also, the HodrickPrescott filter was used to separate positive and negative shocks to investigate the effect of oil price shocks on LNG prices. The results showed that the relationship between LNG and crude oil prices has increased over time and that the effect of price shocks was asymmetric so that the impact of positive shocks was more lasting and more significant than negative shocks. This imbalance indicates that the basic oil contracting mechanism generally works to secure sellers' rights. So Japan needs to reform its contracts. Looking at gas sales contracts elsewhere in the world, it seems that the best alternative to current contracts would be the formation of an LNG hub in the North and East Asian region with the focus on Japan or Singapore.
\end{abstract}

Keywords: OPEC crude oil basket, Japan's LNG import, oil shocks, structural VAR, Hodrick-Prescott filtering, oil-indexation, LNG hub.

\section{Introduction}

In recent years, many countries have taken adequate steps to replace conventional fossil fuels such as kerosene and gas oil with natural gas, due to the numerous economic and environmental benefits of this action .From the environmental point of view, the combustion of natural gas produces less carbon content than coal or oil. Further, from an economic point of view, the use of natural gas is more efficient than other fuels.

The price of natural gas, as well as the changes in its demand and supply, is an extremely vital factor for the majority of economic actors, as this fuel is used not only in many residential and commercial units for heating but as a primary feed in many industries, Specifically for power plants and petrochemical complexes (Nick \& Thoenes, 2013). In general, any increase in oil prices can influence economic growth and the country's products, and consequently, the levels of consumption 
(Lee \& Song, 2012). Therefore, the relationship between crude oil prices and natural gas prices can simultaneously affect consumers, producers, and economic agents (Hartley et al., 2008).

Nevertheless, on the other hand, the low density of natural gas has made shipping and storage often more costly than other fuels, especially crude oil .However, the development of liquefied natural gas (LNG) technology, with fundamental changes in transportation and storage, has led to a reduction in these costs. As a result, natural gas turning into an international commodity (Jensen, 2004).

In pricing literature, there are two models for determining the price level of wholesale natural gas .The first model is based on pricing by the market and the second model through price regulation. The pricing model by the market means that prices have fixed by the interaction of supply and demand forces. Of course, it should be noted that the supply and demand are not necessarily associated with the natural gas market. Indeed, the indexation of prices on other commodities, such as crude oil, coal, petroleum products, or the final electricity production, allows natural gas prices to be determined based on equilibrium in other markets. It should also be noted that the price of natural gas can vary according to the terms of the contract since, in each contract, it is feasible to set the different delivery periods, the range of purchases, as well as the floor and the price cap.

As stated in Tenkate et al. (2013), in the framework of the market price model, three pricing methods are:

1. Oil (production) indexation

2. Gas- on- Gas competition (Hub Price)

3. Netback from the final product

According to trade statistics, most of the imported natural gas in Asia has based on oil-indexed contracts. In 2014, the traded gas in this way (Both pipeline and LNG) in East Asia was 88\% of the overall gas traded in that area, While in Europe, over $60 \%$ of the wholesale gas trading has based on Gas-on-Gas competition or Hub prices (Shi, 2016). Furthermore, in Europe and the United States, most of the gas has sold as pipelines due to access to natural gas reserves and the availability of suitable infrastructure. Nevertheless, in North and East Asia, Natural gas is generally imported as LNG due to the lack of favorable infrastructure and, more importantly, being away from natural gas storage resources.

Since the 1990s, gas pricing across much of Asia has based on the Japanese model, with gas prices being a linear function of crude oil prices as follows:

$$
P=a+b X
$$

Which "P" is the price of imported gas, and "a" is a constant that is determined by negotiation between buyer and seller. The "X" also reflects the price of crude oil, known as the Japanese Crude Cocktail (JCC), which is equal to a basket of several types of crude oil imported from the Middle East. Also, the parameter $b$ is less than one (Fujime, 2015). Further, the floor and cap mechanism, known as the oil price shock absorber, is included in the contract to protect seller and buyer rights against severe oil price fluctuations. In other words, P can only fluctuate in a given domain (Suzuki, 2006).

According to the British Petroleum report in 2018, Japan is one of the major LNG and crude oil importer in the entire world, and most of it has imported from OPEC member countries. Moreover, as mentioned above, Japan is importing its LNG under oil-indexed contracts, so that the OPEC decisions will play a vital role in the determination of LNG prices. However, unlike oil, OPEC does not have the executive power in the natural gas market to stabilize demand and supply, and consequently, the price levels (Dahl et al., 2012). Therefore, in this study, we investigate the structural relationship between OPEC crude oil prices and Japan's LNG import prices.

The structure of this paper is as follows. In section 2, we review some empirical studies linked to gas and oil relationship and their market structure. The data and the primary variables are introduced and analyzed in section 3. In section 4, after reviewing methodology and estimation models, we employ a structural VAR model to observe the responses of LNG price to oil fluctuations and analyze that relationship during our sample period. Further, we use the Hodrick-Prescott filter to distinguish between positive and negative oil shocks to LNG prices, and we investigate whether those shocks act symmetrically. In section 5, Referring to the problems of the oil-indexation pricing model, the alternative model has introduced in the form of a natural gas hub in the region. Eventually, in section 6 , the concluding remark are presented.

\section{Literature review}

Erdös (2012) In his research on the relationship between crude oil and natural gas prices, conclude that since 2008, these prices have decoupled. Skjaeveland and Thompson (2013), in their study, stated that the oil and gas prices were coupled from 1997 to 2006 and started to be decoupled after 2006. Ramberg and Parsons (2012) argued that oil and natural gas prices were co-integrated 
during 1997-2010, but their relationship is changing over time. Villar and Joutz (2006), in their analysis, pointed out that the Henry Hub natural gas prices follow the WTI prices and, further, oil prices leading gas prices, since crude oil possesses an international market, while natural gas has a local market. Barcella (1999) affirmed that there is a co-integration relationship between oil and natural gas prices in the U.S. market, which has referred to long-run economic elements. Panagiotidis and Rutledge (2007) examined the relationship between the wholesale prices of natural gas and the Brent oil during 1996-2003 utilizing the co-integration test. The results confirmed the presence of a long-term relationship between variables. Their conclusions contradicted the hypothesis that these two prices have decoupled over time. Manzoor and Seiflou (2011) investigated the existence of a long-run relationship between crude oil, gas, and coal prices in the U.S. energy market. Based on the result of the co-integration test, they found a long-term linkage between those variables. Asche et al. (2006) Announced crude oil, natural gas, and electricity prices had a long-term relationship in the UK market and concluded there was a primary energy market in the UK, but the price of oil has exogenously fixed .Accordingly, this market is susceptible to variations in oil prices. Hartley et al. (2008) Suggested that there is a clear nexus between the prices of crude oil and natural gas in the US market, but this is an indirect relationship. Natural gas prices tend to react to the global oil price movement; however, the inverse is not the case. That means crude oil prices are not affected by natural gas prices. Geng et al. (2014) investigated the co-integration between Asian natural gas and crude oil prices. They used the Japanese monthly average LNG import prices as the dependent variable for Asia. As a result, they identified that global oil prices have a considerable positive impact on Japan's LNG import prices.

\section{Data and variables}

We consider a structural VAR model based on monthly time series data over the period from January 1997 to October 2017 such that $Y_{t}=\left(\operatorname{DLprod}_{t}, L N G_{t}, O I L_{t}\right)$, where $\operatorname{DLprod}_{t}$ is log differences of OPEC crude oil production in millions of barrels, $L N G_{t}$ is Japan's LNG import price, and $O I L_{t}$ is the price of OPEC crude oil.

Regarding the change in logarithm OPEC crude oil production, we use the oil production data from the International Energy Agency (IEA) in Millions of barrels per day to compute averaged by month. For the data of Japan LNG prices (U.S. Dollars per Million Metric British thermal unit) and OPEC reference basket prices (U.S. Dollar per barrel), we use World Gas Intelligence; World Bank, and monthly oil market reports; OPEC, respectively. The descriptive statistics (Table 1, Appendix) reveals that none of the variables has the normal distribution and the standard deviations clearly show that the volatility is varying through them. However, the existence of a long-run relationship between these variables would be possible. Fig. 1 in the Appendix shows the likelihood of a long-term relationship between OPEC crude oil prices and Japan's imported LNG prices multiply by 10 (For a better comparison of the trends). The graph clearly shows that the price of the LNG responds to oil price changes with a short delay. Also, Based on Dickey and Fuller (1981) unit root test (Table 2, Appendix), the series $L N G_{t}$ and $O I L_{t}$ are I(1) while $\operatorname{LLprod}_{t}$ is I(0). After that, by employing Johansen's (1988) co-integration tests, we examine whether those series are co-integrated. The results (Table 3, Appendix) confirm the existence of a long-term relationship between them. Therefore, without any concern about constructing a fake model, we use a VAR system of the equation to investigate the relationship between crude oil and LNG prices.

\section{Methodology and estimation}

In this section, the SVAR model will perform in order to determine the effects of OPEC crude oil price shocks on the Japanese LNG import price. Also, the Hodrick-Prescott filtering will apply to distinguish between positive shocks and negative shocks to analysis the effects of them, independently. Nevertheless, since this paper examines OPEC oil price shocks on Japan's imported LNG prices, the first step is to see whether the oil price is affecting the price of LNG. For this purpose, before each analysis, we examine the causality relationship between these two variables. Since both time series have the unit root, it is not possible to use the Granger (1969) causality test because the initial assumption of this test is the stationary of the time series. Therefore, the Toda and Yamamoto (1995) test, which is a modified form of the Granger test, is used. The results of this test are reported in Table 1. 
Table 1: Causality test results

Dependent Variable: LNG

\begin{tabular}{llll}
\hline Excluded & Chi-sq & df & Prob \\
OIL & 338.22 & 7 & 0.00 \\
\hline Dependent Variable: OIL & & & \\
\hline Excluded & Chi-sq & df & Prob \\
LNG & 6.40 & 7 & 0.49 \\
\hline
\end{tabular}

The results of the above table clearly show that the causal relationship is from the price of oil to the price of LNG, while the opposite is not the case, and then LNG prices are profoundly affected by oil prices, but LNG prices do not affect oil prices. Therefore, it can be concluded that OPEC oil price shocks have a significant effect on Japan's imported LNG prices; however, determining the impact level requires more investigation, which will be discussed further.

\subsection{Structural VAR}

The structural VAR is based on Zamani (2016), Jadidzadeh and Serletis (2017), and Kilian (2009), but with the exclusion of a variable. Because we discuss two departed systems (not a united set like U.S. oil and gas market), first Japan and its LNG import and the second OPEC member countries and their oil export, and we do not consider them as a homogeneous collection. We know that the OPEC consists of several countries with almost different economic structures; therefore, for avoiding any incorrect conclusion, we decide to exclude the variable "real economic activity" from the basic model. So, we employ an SVAR for modeling the relationship between OPEC crude oil prices and Japanese LNG import prices to examine the effect of different types of crude oil shocks on that liquefied natural gas.

In the reduced form representation, our model is denoted as:

$$
Z_{t}=\delta+\sum_{1}^{p} B_{i} Z_{t-i}+e_{t}
$$

Where $e_{t}$ is the vector of reduced form errors, and also as suggested by Kilian (2009), $P=24$. We estimate the equation (2) using the least square method (OLS), which is used in the structural VAR model. The model in its SVAR representation has written as:

$$
A_{0} Z_{t}=\alpha+\sum_{1}^{p} A_{i} Z_{t-i}+\varepsilon_{t}
$$

Which $\varepsilon_{t}$ is the vector of serially and mutually uncorrelated structural errors. We postulate a recursive structure for our model, $A_{0}^{-1}$, Such that the reduced form errors, $e_{t}$, can be written according to $e_{t}=A_{0}^{-1} \varepsilon_{t}$, where we can obtain a lower triangular matrix, $A_{0}^{-1}$, by using the Cholesky decomposition algorithm.so will have:

$$
e_{t}=\left(\begin{array}{c}
e_{t}^{\text {DLprod }} \\
e_{t}^{L N G} \\
e_{t}{ }^{\text {OIL }}
\end{array}\right)=\left(\begin{array}{ccc}
a_{11} & 0 & 0 \\
a_{21} & a_{22} & 0 \\
a_{31} & a_{32} & a_{33}
\end{array}\right)\left(\begin{array}{c}
\varepsilon_{t} \text { OPEC production } \\
\varepsilon_{t}^{L N G \text { price }} \\
\varepsilon_{t}^{\text {OPEC price }}
\end{array}\right)
$$

After estimating the reduced form VAR, then we use the results to calculate impulse response functions to one-standard-deviation shocks. In Fig. 1, we illustrate the responses on the LNG prices to each of the other structural shocks. As can be seen in Fig. 1, the shocks have very different effects on the price of LNG. The variance decomposition in Table 2, quantify the effects of the structural shocks on the price of Japanese LNG import. As can be seen, oil price shocks in the short-run are negligible, but in the long-run, oil price shocks account for about $73 \%$ of the variability in the price of LNG. 
Figure 1: Impulse responses of structural shocks to LNG prices/ 1997-2017

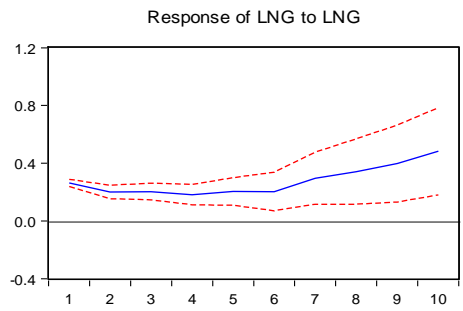

Response to Cholesky One S.D. Innovations \pm 2 S.E.
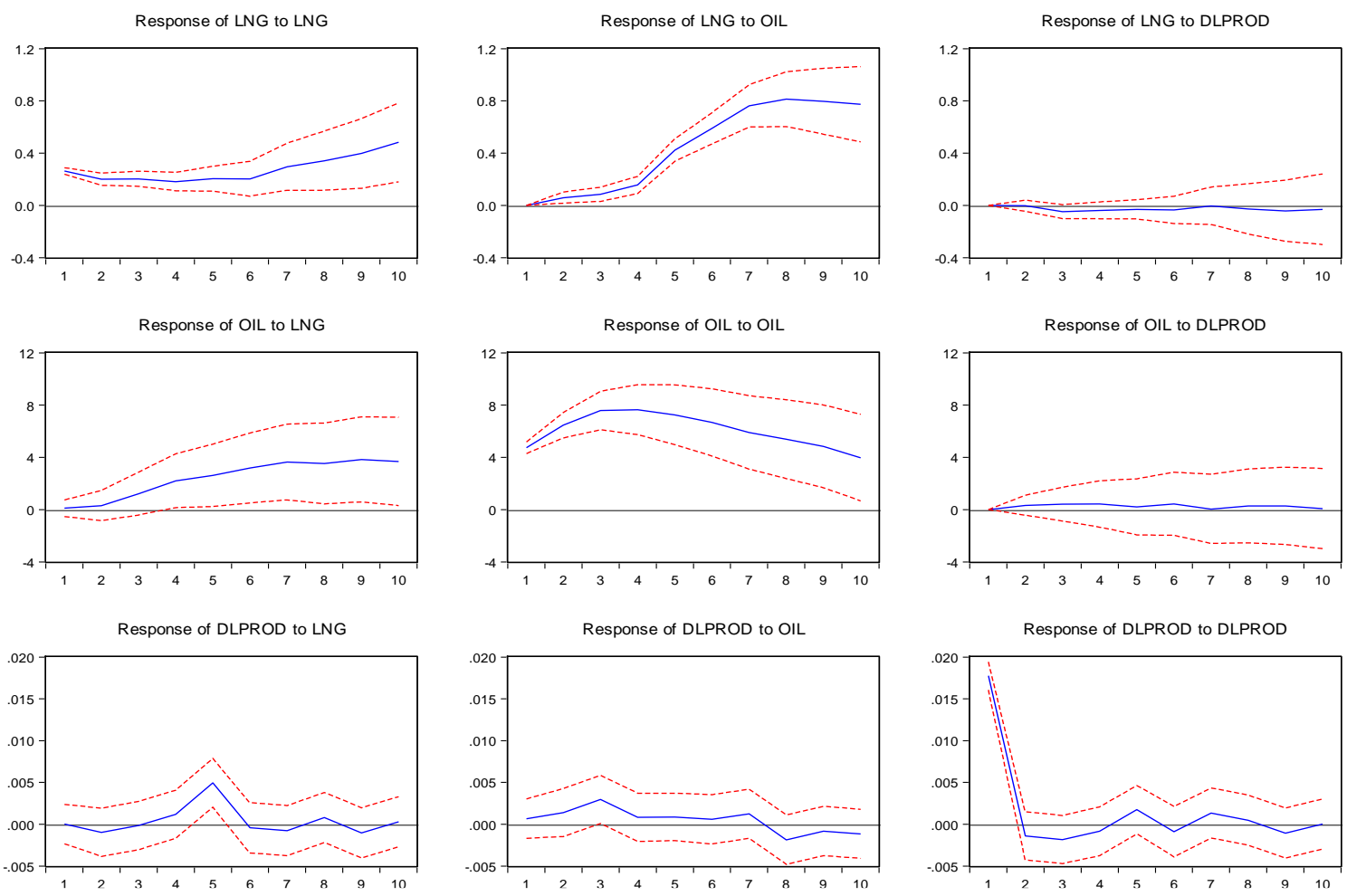

\begin{tabular}{cccc}
\hline \multicolumn{3}{c}{ Table 2: Percent contribution of shocks to the overall variability of the LNG prices } \\
\hline Horizon & LNG & OIL & DLPROD \\
\hline 1 & 100 & 0 & 0 \\
3 & 96.87 & 3.11 & 0.02 \\
24 & 92.08 & 6.50 & 1.42 \\
50 & 32.53 & 66.19 & 1.28 \\
& 23.72 & 73.46 & 2.82 \\
\hline
\end{tabular}

Notes: Variance decomposition of the structural VAR, 1997-2017

\subsection{Historical decomposition}

Since the sample period that has used in this paper contain 250 monthly observation, this may lead to instability in our estimation; therefore, we suggest an analysis based on two sub-samples. According to the OPEC website, until 2008, Indonesia was an active member of the organization, and after that year, it terminated its membership. Also, due to British Petroleum reports (Annual Statistical Reviews), Indonesia is the primary LNG provider for Japan, and except this country, just four other countries in OPEC have a contribution to Japan's LNG import (UAE, Qatar, Nigeria, and Algeria). So, after 2008, the total shares of OPEC members in Japanese LNG import got decreased. Along with this, the US financial and economic crisis, which led to the collapse of its stock exchange and subsequent stock collapse in other countries, including Japan, took place between 2007 and 2008. Due to this breaking point, we decomposed the whole period to two sub-periods, before 2009 and after that. Furthermore, we used a VAR model to analyze the effect of oil prices on LNG prices within each sub-period.

\subsubsection{Before 2009}

For the period during 1997-2008, because the number of observation is not sufficiently large, we estimate our model with optimal lags that suggested by the Hannan and Quinn (1979) criterion (to avoid the over-fitting problem; we employ $\mathrm{H}-\mathrm{Q}$ instead of AIC), $P=2$. The impulse response functions of LNG price to oil price illustrated in Fig 2. Also, the variance decompositions reported in Table 3, and it has shown that in the long run, oil price shocks can explain about $89 \%$ of the variation in the price of LNG. 
Figure 2: Impulse responses of structural shocks to LNG prices, 1997-2008

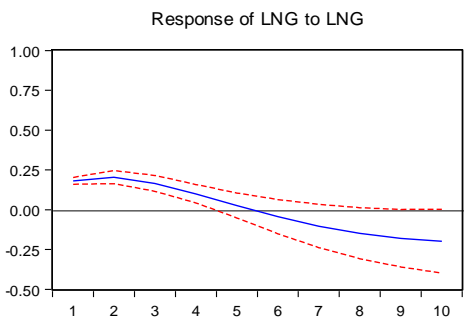

Response to Cholesky One S.D. Innovations \pm 2 S.E.
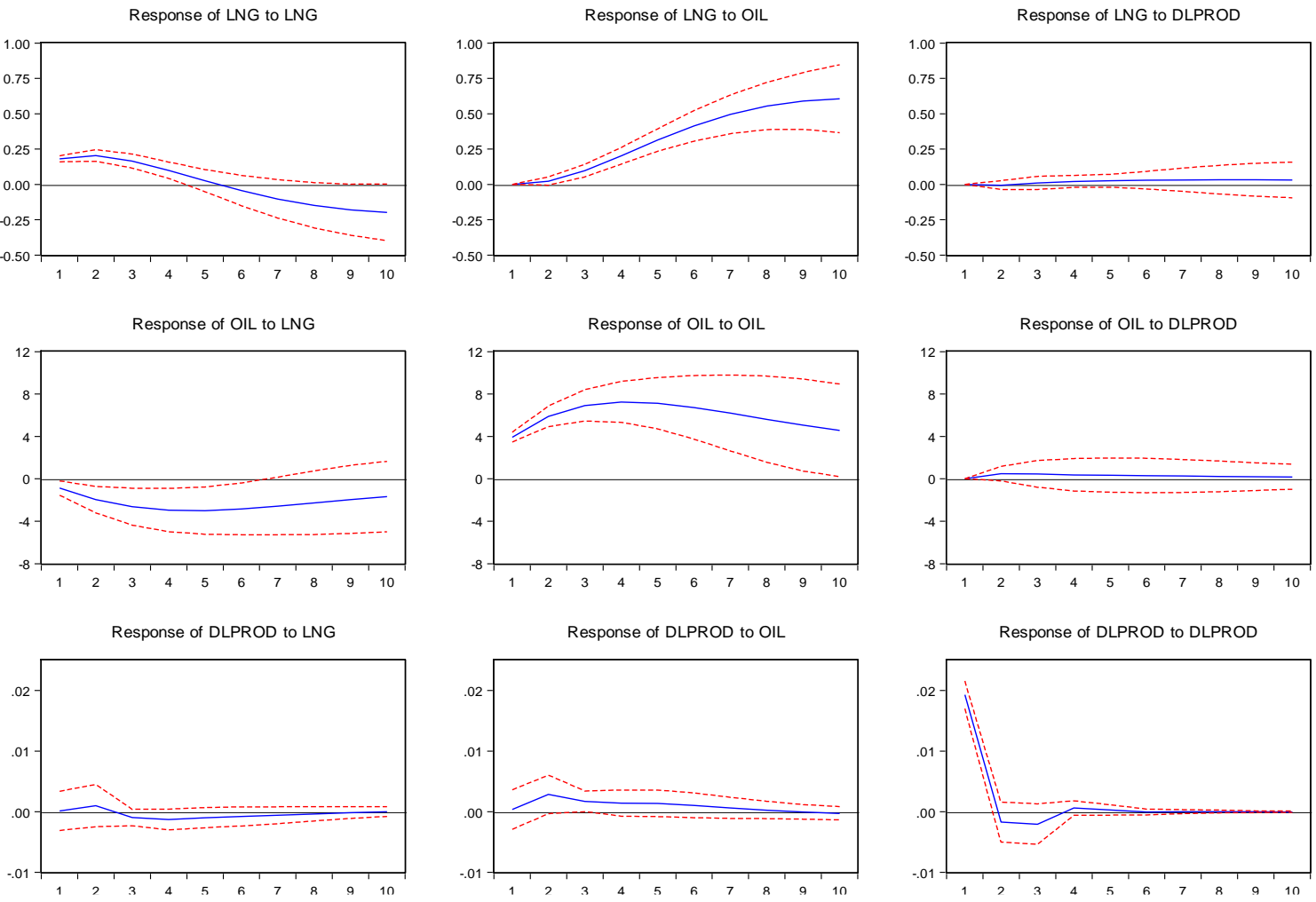

Table 3: Percent contribution of shocks to the overall variability of the LNG prices

\begin{tabular}{cccc}
\hline Horizon & LNG & OIL & DLPROD \\
\hline 1 & 100 & 0 & 0 \\
2 & 99.25 & 0.70 & 0.05 \\
3 & 90.99 & 8.87 & 0.14 \\
24 & 10.69 & 89.06 & 0.25 \\
50 & 10.29 & 89.47 & 0.24 \\
\hline
\end{tabular}

Notes: Variance decomposition of the structural VAR, 1997-2008

\subsubsection{After 2009}

For this period, during 2009-2017 (until October 2017), the suggested optimal lag was $P=4$ (just like above, we employ $\mathrm{H}-\mathrm{Q}$ instead of AIC). So, we illustrate the impulse response functions and the variance decompositions in Fig. 3 and Table 4, respectively. The results have shown that in the long run, oil price shocks can explain about $93 \%$ of fluctuations in the LNG price.

The comparison between the results of those two sub-periods indicates that during 19972017, not only OPEC crude oil price had a significant impact on Japanese LNG import price, but also its effect got stronger during the time. Likewise, over the period two, the average oil prices were much higher than the period one. Therefore, for more analysis, it seems necessary to study about two sides of oil shocks, positive shocks, and negative shocks. 
Figure 3: Impulse responses of structural shocks to LNG prices/ 2009-2017

Response of LNG to LNG

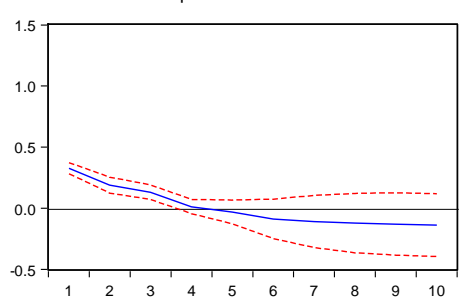

Response of OIL to LNG

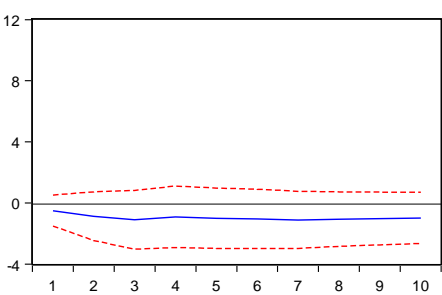

Response of DLPROD to LNG

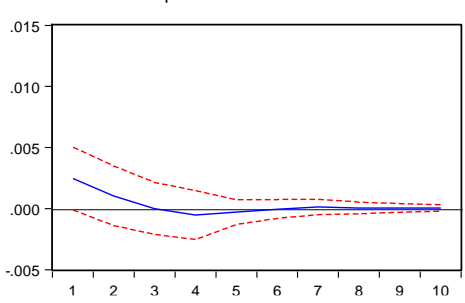

Response to Cholesky One S.D. Innovations \pm 2 S.E.
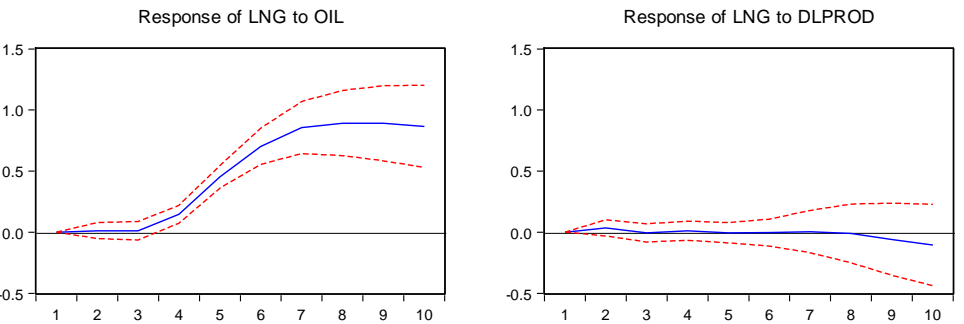

Response of OIL to OIL

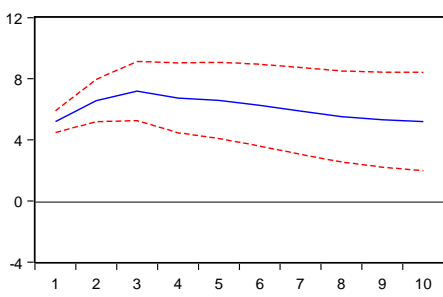

Response of OIL to DLPROD

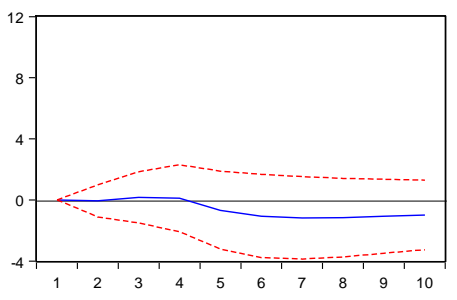

Response of DLPROD to OIL
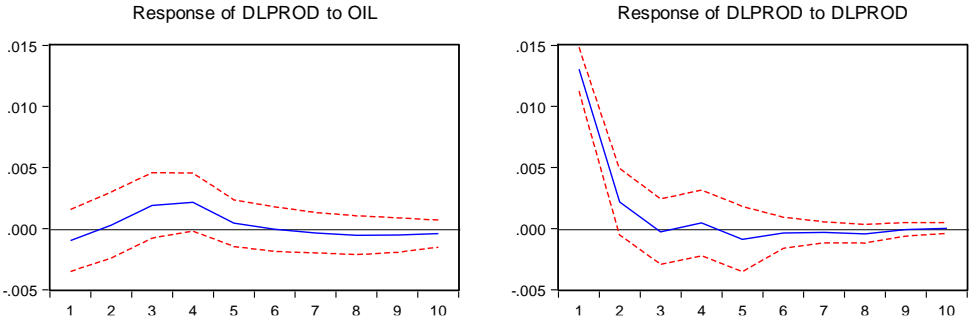

Table 4: Percent contribution of shocks to the overall variability of the LNG prices

\begin{tabular}{cccc}
\hline Horizon & LNG & OIL & DLPROD \\
\hline 1 & 100 & 0 & 0 \\
2 & 99.07 & 0.10 & 0.83 \\
3 & 99.07 & 0.17 & 0.76 \\
24 & 4.20 & 93.77 & 2.03 \\
50 & 4.05 & 93.69 & 2.26 \\
\hline
\end{tabular}

Notes: Variance decomposition of the structural VAR, 2009-2017

\subsection{The Hodrick-Prescott filtering}

A popular method of decomposing a single shock to positive and negative shocks is using univariate Hodrick and Prescott (1997) filter. This smoothing filtering is widely used in real business cycle theory to separate the cyclical component of a time series from raw data, the outcomes for the logarithm of oil price filtering illustrated in Fig. 4.

Figure 4: Hodrick-Prescott filtering of the logarithm of oil prices, 1997-2017

Hodrick-Prescott Filter (lambda=14400)

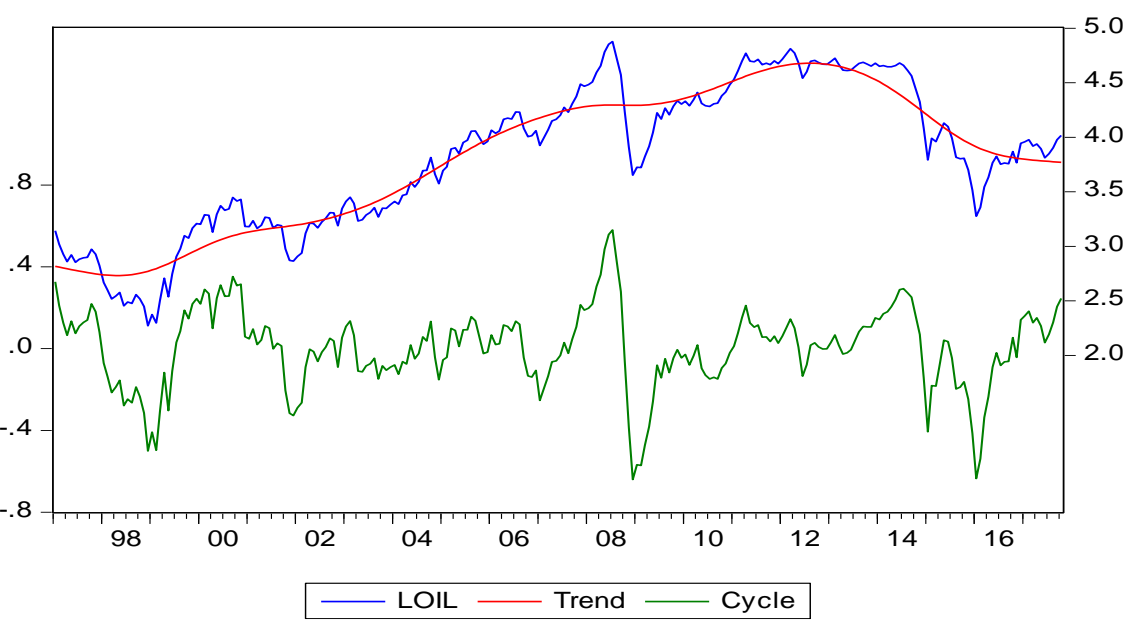



follows:

Definition of positive and negative shocks based on Rezazadeh Karsalari et al. (2013) is as

$$
\begin{gathered}
\text { First Step Shock }=\log (\text { Oil })-\text { Value from " } H-P " \text { filtering Log }(\mathrm{Oil}) \\
\text { Second Step } \\
\left\{\begin{array}{l}
\text { Positive } \text { shock }=\text { Max }(\text { Shock, } 0) \\
\text { Negative Shock }=\text { Min }(\text { Shock, } 0)
\end{array}\right.
\end{gathered}
$$

In the next step, we test the existence of unit root in positive and negative shocks. The ADF test indicates that the two series are stable. Because all four variables are stationary, we can say with certainty that there is at least one long-run equilibrium between variables, DLLNG as differences logarithm of LNG prices, POS as the positive shock, NEG as the negative shock, and DLPROD as differences logarithm of oil production (results of ADF test reported in Table A4 in Appendix). In the final step, we employ a structural VAR model based on the variables as mentioned earlier (with optimal lag $P=6$, suggested by AIC) to investigate the effects of each type of OPEC crude oil price shocks on Japanese LNG import price. Impulse response functions plot in Fig. 5 and variance decompositions reported in Table 5. The results indicate that in the long run, the effects of positive shocks were higher than negative shocks, but the differences between them were not too much.

Figure 5: Impulse responses of structural shocks to LNG prices/ Hodrick-Prescott filtering
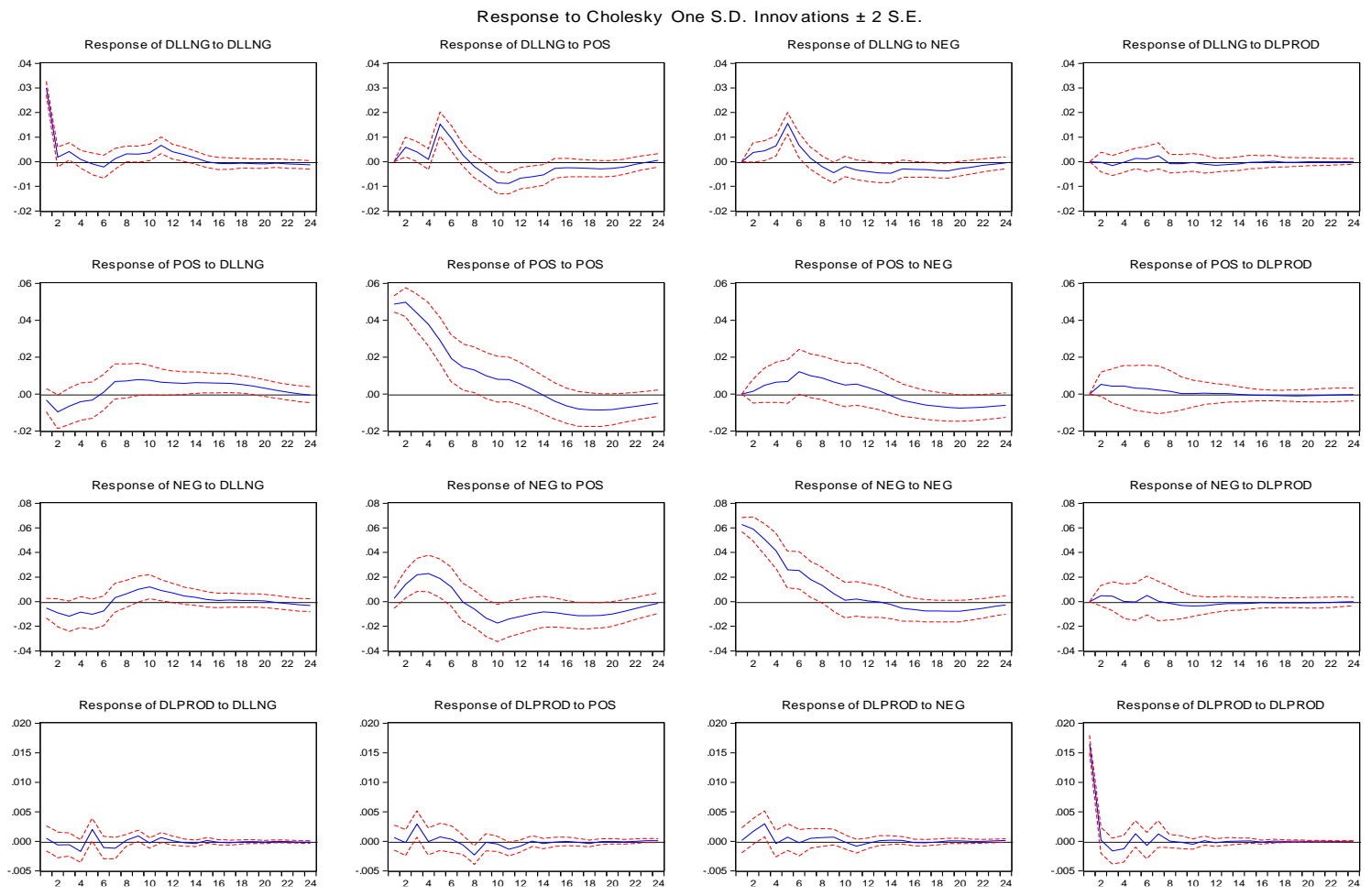

Table 5: Percent contribution of shocks to the overall variability of the log LNG prices

\begin{tabular}{ccccc}
\hline Horizon & DLLNG & POS & NEG & DLPROD \\
\hline 1 & 100 & 0 & 0 & 0 \\
2 & 94.82 & 3.67 & 1.48 & 0.03 \\
3 & 91.37 & 5.05 & 3.33 & 0.25 \\
4 & 87.62 & 4.91 & 7.22 & 0.25 \\
5 & 60.16 & 18.70 & 20.85 & 0.29 \\
6 & 55.35 & 22.53 & 21.77 & 0.35 \\
24 & 44.76 & 31.40 & 23.05 & 0.79 \\
50 & 43.92 & 32.01 & 23.28 & 0.79 \\
\hline
\end{tabular}

Notes: Variance decomposition of the structural VAR / Hodrick-Prescott

\section{Optimal LNG Policy}

In the previous section, we observed that the dependence of natural gas prices on crude oil has gradually increased. Also, positive shocks of crude oil prices against negative shocks have a more lasting effect on rising LNG prices, which shows that the cap and floor price mechanism in the contract is more likely to support sellers. We are also witnessing numerous political and military 
upheavals in the oil-rich Middle East region, which supplies virtually a large portion of Japan's imported crude and is also the basis for the JCC parameter setting. These problems can cause severe price volatility. Therefore, LNG imports based on the oil-indexation model appear to increase economic uncertainty. As a result, Japan needs to reform its import contracts as well as diverse its LNG suppliers.

According to the constraints of the LNG industry in East and North Asia, along with the lack of development of a pipeline-based transmission system as well as the absence of a coherent natural gas market, what is the best solution for Japan? It seems that creating an LNG hub in the region can help to increase the transparency of contracts as well as create a more regulated market by organizing buyers and sellers. It can also guarantee the rights of buyers and sellers alike. Most importantly, it avoids imposing severe oil price shocks on the economy of LNG importing countries. Natural gas pricing in the United States (Henry Hub) and Europe have based on Hub prices, and this has caused the price of natural gas in these areas to be significantly lower than in Asia when crude oil prices rise (IEA, 2013). The creation of a price hub will also lead to contract flexibility and market stability for this product in North and East Asia (Shi, 2016). It should mention that while there is no LNG hub in Asia yet, there are some well-positioned Price benchmarks such as Singapore (Fulwood, 2018).

Therefore, it seems that collaboration among major LNG importing countries such as Singapore, Japan, and South Korea, to create an LNG Hub could benefit all industry players, especially consumers. It should be remembered, however, that creating a hub requires many backgrounds, including the liberalization of the natural gas and electricity markets, to create competition. Besides, the convergence between the LNG market and the natural gas (pipeline) market, as well as the possibility for third parties (other countries) to use pipelines and LNG terminals, are among the requirements of creating a price hub.

\section{Conclusion}

In this paper, Japan's LNG import contracts are studied in light of the fact that their pricing is based on the oil-indexation model. In this regard, we concentrated on the relationship between the OPEC crude oil basket prices and Japanese LNG import prices, using a structural VAR model based on monthly observations from January 1997 to October 2017. The results from impulse response functions and variance decompositions reveal that in long-run, about $73 \%$ of volatility in LNG prices could account on crude oil prices, but because of the time interval and its possible instability effect on results (250 monthly data) and also the fact that at the end of 2008, Indonesia as a major LNG provider for Japan, terminated its membership in OPEC, we divided whole period to two sub-periods, period one: 1997:01 to 2008:12, and period two, 2009:01 to 2017:10, and employed a VAR model for each of them, separately. The results indicated that during the original period, the dependency between LNG and crude oil prices got increased. This change must be referred to increases in oil prices during period two in compare period one. The average price of OPEC crude oil in the first period was 38.51 Dollars per barrel, while this value in the second period was 78.08. Also, most of Japan's LNG import is under long-term conditions, and its contracts are oil-indexed. Therefore, it sounds logical that the dependency between them increased. In order to robust this hypothesis, we used the Hodrick-Prescott filter to break down the oil shocks to positive and negative shocks to measure and compare the effect of each shock on LNG price, independently. The results of the analysis of structural VAR based on positive and negative shocks demonstrated that in the long-run, the effects of positive shocks were higher than negative shocks. This fact, in addition to the results of historical decomposition, will prove our hypothesis that indicates during the sample period, the relationship between OPEC crude oil price and Japan's LNG import price increased. Also, this asymmetry reveals that the oil-indexation contract generally tends to support the LNG seller. Therefore Japan needs a new version of the LNG contract.

Finally, by analyzing various natural gas pricing models, especially in the United States (Henry Hub), this study concluded that the best alternative to oil-indexation contracts to avoid imposing oil price shocks is to establish an LNG hub in the area. Hub pricing can partially control fluctuations and allow for the creation of a natural gas market in the region. The Hub formation will ultimately benefit consumers by creating competition and transparency in natural gas trading.

\section{Appendix A. Supplementary material}

Supplementary data associated with this article can be found, in the online version, at https://doi.org/10.14254/jems.2020.5-1.3 


\section{Funding}

The authors received no direct funding for this research.

\section{Conflict of Interest}

The author declares that he has no conflict of interest.

\section{Citation information}

Raeisi Sarkandiz, M. (2020). Is this essential for Japan to changes its LNG import policy? Some evidence of the OPEC crude oil price shocks. Economics, Management and Sustainability, 5(1), 29-41. doi:10.14254/jems.2020.5-1.3.

\section{References}

Asche, F., Osmundsen, P., \& Sandsmark, M. (2006). The UK market for natural gas, oil and electricity: are the prices decoupled?. The Energy Journal, 27(2), 27-40.

Barcella, M. L. (1999, May). The pricing of gas. In Oxford Energy Forum. Oxford Institute for Energy Studies, Oxford. May.

Petroleum, B. (2018). British Petroleum Statistical Review of World Energy. British Petroleum Corporate Communications Services, London.

Dahl, R. E., Oglend, A., Osmundsen, P., \& Sikveland, M. (2012). Are oil and natural gas going separate ways in the United Kingdom? Cointegration tests with structural shifts. The Journal of Energy Markets, 5(2), 33-58.

Dickey, D. A., \& Fuller, W. A. (1981). Likelihood ratio statistics for autoregressive time series with a unit root. Econometrica: Journal of the Econometric Society, 1057-1072.

Erdős, P. (2012). Have oil and gas prices got separated?. Energy Policy, 49, 707-718.

Fujime, K. (2015). LNG Market and Price Formation in East Asia. Institute of Energy Economics, Japan.

Fulwood, M. (2018). Asian LNG Trading Hubs: Myth or Reality?. Center on Global Energy Policy, May.

Geng, J. B., Ji, Q., \& Fan, Y. (2014). A dynamic analysis on global natural gas trade network. Applied Energy, 132, 23-33.

Granger, C. W. J. (1696). Investigating Causal Relations by Econometric Models and Cross-Spectral Methods. Econometrica, 37(3), 424-438.

Hannan, E. J., \& Quinn, B. G. (1979). The determination of the order of an autoregression. Journal of the Royal Statistical Society: Series B (Methodological), 41(2), 190-195.

Hartley, P. R., Medlock III, K. B., \& Rosthal, J. E. (2008). The relationship of natural gas to oil prices. The Energy Journal, 29(3), 47-65.

Hodrick, R. J., \& Prescott, E. C. (1997). Postwar US business cycles: an empirical investigation. Journal of Money, Credit, and Banking, 29(1), 1-16.

Jadidzadeh, A., \& Serletis, A. (2017). How does the US natural gas market react to demand and supply shocks in the crude oil market?. Energy Economics, 63, 66-74.

Jarque, C. M., \& Bera, A. K. (1980). Efficient tests for normality, homoscedasticity and serial independence of regression residuals. Economics Letters, 6(3), 255-259.

Jensen, J. T. (2004). The development of a global LNG market: is it likely? If so, when?. Oxford Institute for Energy Studies.

Johansen, S. (1988). Statistical analysis of cointegration vectors. Journal of Economic Dynamics and Control, 12(2-3), 231-254.

Kilian, L. (2009). Not all oil price shocks are alike: Disentangling demand and supply shocks in the crude oil market. American Economic Review, 99(3), 1053-69.

Lee, J., \& Song, J. (2012). Oil and Small Open Macroeconomy: A case of Korea. Global Economic Review, 41(1), 77-95. 
Manzoor, D., \& Seiflou, S. (2011). Are crude oil, gas and coal prices co integrated?. Iranian Economic Review, 15(28), 29-51.

Nick, S., \& Thoenes, S. (2013). What drives natural gas prices? A structural VAR approach. Institute of Energy Economics at the University of Cologne, EWI Working Paper No. 13/02, Germany.

Ramberg, D. J., \& Parsons, J. E. (2012). The weak tie between natural gas and oil prices. The Energy Journal, 33(2), 13-35.

Rezazadeh Karsalari, A., \& Behrooznia, F. H. A. (2013). The effects of oil price shocks on real GDP in Iran. African Journal of Business Management, 7(33), 3220-3232.

Skjæveland, K., \& Thompson, T. H. (2013). The end of a long term relationship between the price of crude oil and natural gas: a cointegration approach (Master's thesis). University of Bergen, Norway.

Ten Kate, W., Varró, L., \& Corbeau, A. S. (2013). Developing a Natural Gas Trading Hub in Asia: Obstacles and Opportunities. International Energy Agency.

Toda, H. Y., \& Yamamoto, T. (1995). Statistical inference in vector autoregressions with possibly integrated processes. Journal of Econometrics, 66(1-2), 225-250.

Panagiotidis, T., \& Rutledge, E. (2007). Oil and gas markets in the UK: Evidence from a cointegrating approach. Energy economics, 29(2), 329-347.

Villar, J. A., \& Joutz, F. L. (2006). The relationship between crude oil and natural gas prices. Energy Information Administration, Office of Oil and Gas, 1-43. Retrieved from http://www.uprm.edu/aceer/pdfs/CrudeOil_NaturalGas.pdf.

World Energy Council. (2013). World Energy Resources: Natural gas. London.

Suzuki, T. (2006). Future LNG price in Asian market. Tokyo Institute of Energy Economics, Japan.

Shi, X. (2016). The Impact of Low Oil Prices on Natural Gas and the Implications for the Asia-Pasific. Pacific Energy Summit, Working Paper, Singapore.

Zamani, N. (2016). How the crude oil market affects the natural gas market? Demand and supply shocks. International Journal of Energy Economics and Policy, 6(2), 217-221. 


\section{Appendix}

Table A1: Descriptive statistics

\begin{tabular}{lcccccc}
\hline Variable & Mean & Std. Dev & Skewness & Kurtosis & J-B (stat) & J-B (Prob) \\
\hline LNG & 8.33 & 4.50 & 0.70 & 2.16 & 28.15 & 0.00 \\
Oil & 55.29 & 32.99 & 0.52 & 2.00 & 21.51 & 0.00 \\
DLPROD & 0.00 & 0.01 & -0.72 & 5.99 & 114.79 & 0.00 \\
\hline
\end{tabular}

Notes: the J-B referred to the Jarque and Bera (1980) normality test.

Figure A1: The Trend of Oil and LNG Prices, 1997-2017

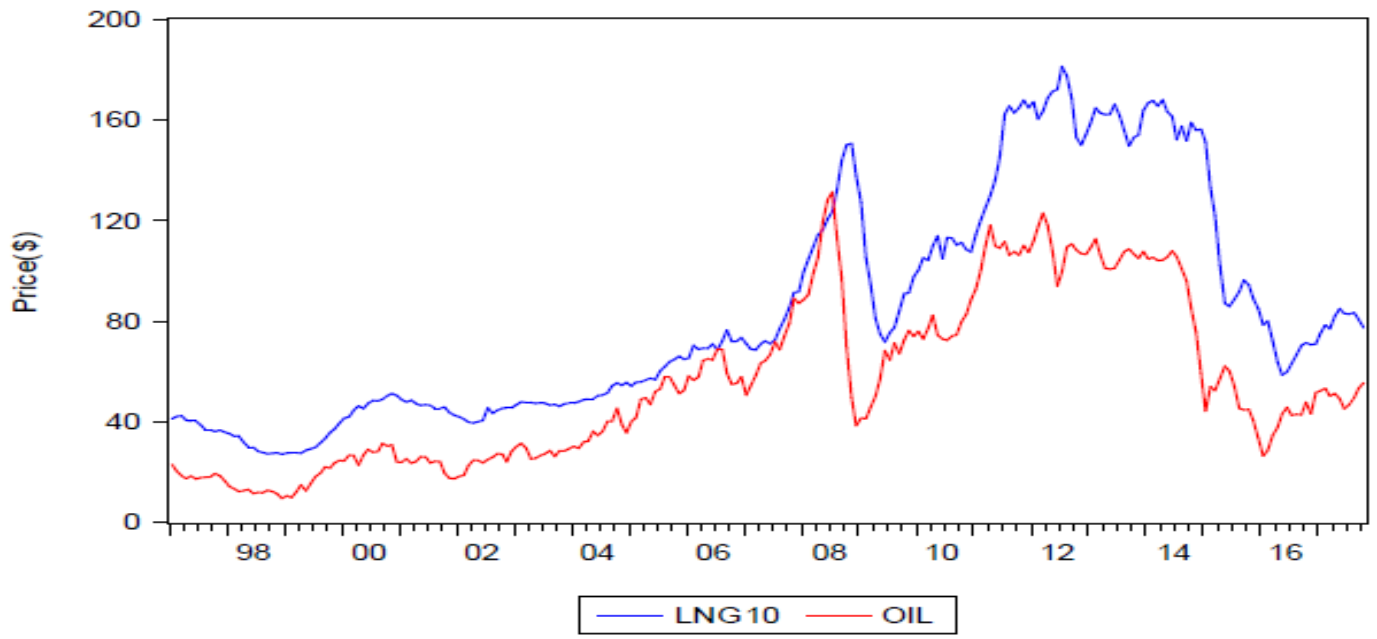

\begin{tabular}{|c|c|c|c|c|c|c|}
\hline & \multicolumn{2}{|c|}{ DLPROD } & \multicolumn{2}{|c|}{ D(LNG) } & \multicolumn{2}{|c|}{$\mathrm{D}(\mathrm{OIL})$} \\
\hline & Statistic & $\begin{array}{c}\text { Critical } \\
\text { Value }\end{array}$ & Statistic & $\begin{array}{c}\text { Critical } \\
\text { Value }\end{array}$ & Statistic & $\begin{array}{c}\text { Critical } \\
\text { Value }\end{array}$ \\
\hline No Intercept & & -2.57 & & -2.57 & & -2.57 \\
\hline No Trend & -15.46 & $\begin{array}{l}-1.94 \\
-1.61\end{array}$ & -6.48 & $\begin{array}{l}-1.94 \\
-1.61\end{array}$ & -9.95 & $\begin{array}{l}-1.94 \\
-1.61\end{array}$ \\
\hline Intercept & & -3.45 & & -3.45 & & -3.45 \\
\hline No Trend & -15.46 & $\begin{array}{l}-2.87 \\
-2.57\end{array}$ & -6.47 & $\begin{array}{l}-2.87 \\
-2.57\end{array}$ & -9.94 & $\begin{array}{l}-2.87 \\
-2.57\end{array}$ \\
\hline
\end{tabular}

\begin{tabular}{ll} 
Table A3: The Johansen test Results, & $\mathbf{1 9 9 7 - 2 0 1 7}$ \\
\hline Sample (Adjusted) & 1999M03 - 2017M10 \\
& \\
Include Observation & 224 After Adjustments \\
Trend Assumption & Linear Deterministic Trend \\
Series & LNG - OIL - DLPROD \\
Lag Interval (In First Differences) & 1 to 24 \\
\hline & Trace Test Indicates 1 Co-integrating Eqn(s) at the 0.05 Level \\
Result & Max- Eigenvalue Test Indicates 1 Co-integrating Eqn(s) at the \\
& 0.05 Level \\
\hline
\end{tabular}




\begin{tabular}{|c|c|c|c|c|c|c|c|c|}
\hline & \multicolumn{2}{|l|}{ DLPROD } & \multicolumn{2}{|l|}{ D(LLNG) } & \multicolumn{2}{|l|}{ POS } & \multicolumn{2}{|l|}{ NEG } \\
\hline & Statisti & $\begin{array}{l}\text { Critical } \\
\text { Value }\end{array}$ & Statistic & $\begin{array}{l}\text { Critical } \\
\text { Value }\end{array}$ & Statistic & $\begin{array}{l}\text { Critical } \\
\text { Value }\end{array}$ & Statistic & $\begin{array}{l}\text { Critical } \\
\text { Value }\end{array}$ \\
\hline No & & -2.57 & & -2.57 & & -2.57 & & -2.57 \\
\hline Intercept & -15.46 & -1.94 & -6.53 & -1.94 & -3.71 & -1.94 & -4.36 & -1.94 \\
\hline No Trend & & -1.61 & & -1.61 & & -1.61 & & -1.61 \\
\hline Intercept & & -3.45 & & -3.45 & & -3.45 & & -3.45 \\
\hline No Trend & -15.46 & -2.87 & -6.53 & -2.87 & -4.67 & -2.87 & -5.15 & -2.87 \\
\hline & & -2.57 & & -2.57 & & -2.57 & & -2.57 \\
\hline
\end{tabular}



(c) 2016-2020, Economics, Management and Sustainability. All rights reserved.

This open access article is distributed under a Creative Commons Attribution (CC-BY) 4.0 license.

Share - copy and redistribute

The licensor cannot revoke these freedoms as long as you follow the license terms.

Under the following terms:

Attribution - You must give appropriate credit, provide a link to the license, and indicate if changes were made

You may do so in any reasonable manner, but not in any way that suggests the licensor endorses you or your use.

No additional restrictions

You may not apply legal terms or technological measures that legally restrict others from doing anything the license permits.

conomics, Management and Sustainability (ISSN: 2520-6303) is published by Scientific Publishing House "CSR",

Poland, EU and Scientific Publishing House "SciView", Poland

Publishing with JEMS ensures:

Immediate, universal access to your article on publication

- High visibility and discoverability via the JEMS website

- Rapid publication

- Guaranteed legacy preservation of your article

Discounts and waivers for authors in developing regions

Submit your manuscript to a JEMS at http://jems.sciview.net or submit.jems@sciview.net 